\title{
ON THE SUBGENUS EURYSUNIUS REITTER OF TURKEY IV. A NEW SPECIES FROM SOUTHWESTERN ANATOLIA WITH A KEY TO SPECIES (COLEOPTERA: STAPHYLINIDAE, PAEDERINAE, ASTENUS)
}

\author{
SinAn AnLaş \\ Celal Bayar University, Alaşehir Vocational School \\ TR-45600 Alaşehir, Manisa, Turkey; E-mail: sinan.anlas@gmail.com
}

Astenus (Eurysunius) goeki sp. n. from Antalya province, in southwestern Anatolia is described, illustrated, and distinguished from related consubgeners. A total of 15 species is known so far from Turkey. A key to all the species of Eurysunius in this country is provided.

Key words: Coleoptera, Staphylinidae, Paederinae, Astenus, Eurysunius, Tetramorium, Turkey, new species, key to species.

\section{INTRODUCTION}

Eurysunius, subgenus of Astenus Dejean was established by ReItTer (1909) and currently includes 59 described species from the Palaearctic region. They are distributed mainly in the Mediterranean countries (SchüLKE \& SMETANA 2015). There are 14 species present in Turkey, 13 of them are endemic to this country (Assıng 2002, 2007, 2010, 2011, 2013, 2015, AnLAş 2014, 2015, 2016).

The nests of ants (Hymenoptera: Formicidae) provide a suitable habitat for a wide range of beetles. Staphylinidae represent one of the most speciose families of the order Coleoptera, which inhabit ant nests commonly known as myrmecophiles (Donisthorpe 1927, Hölldobler \& Wilson 1990). The genus Tetramorium Mayr, 1855 (Formicidae: Myrmicinae) is one of the biggest ant genera, comprising more than 430 species in the world (Bolton 1995). According to Assing $(2002,2003,2007)$ Eurysunius species are most probably associated with ants of the genus Tetramorium, at least some of them facultatively. According to my observations, this is true for all my recorded Euryunius species, which were collected in nests of Tetramorium species in Turkey.

The aim of the paper is to describe a new species of Eurysunius from Turkey and to provide a key to the 15 species comprising currently the subgenus in Turkey. 


\section{MATERIAL AND METHODS}

The present paper is based on material collected during a recent field study in the southwestern Anatolia, in late summer 2015. The reference specimens in this study are deposited in the collection of the Alaşehir Zoological Museum, Manisa (AZMM) of the Celal Bayar University. Primary and secondary sexual characters of the species described herein are termed following Coiffait (1984) and Assing (2002). The morphological studies were conducted using a Stemi 2000-C microscope (Zeiss, Germany), combined with a digital camera (Zeiss Axiocam ERC5s) for the photographs.

Head length was measured from the anterior margin of the frons to the posterior margin of the head, length of pronotum was measured along the median line, elytral length was measured at the suture from the apex of the scutellum to the posterior margin of the elytra. The length of the median lobe of the aedeagus was measured from the apex of the ventral process to the base of the capsule.

\section{TAXONOMY}

\section{Astenus (Eurysunius) goeki sp. $\mathrm{n}$.}

(Figs 1-6)

Type material - Holotype: TURKEY: $\widehat{\delta}$ “TR - Antalya province, Finike, Alacadağ,

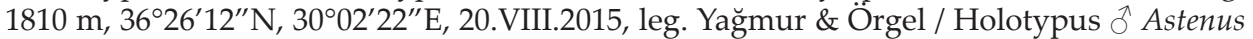
(Eurysunius) goeki sp. n. det. S. Anlaş 2016" (AZMM). Paratypes: TURKEY: 1 , same data as holotype (AZMM); $2 \stackrel{0}{\circ} 1$, Antalya province, Finike, Alacadağ, $1620 \mathrm{~m}, 36^{\circ} 26^{\prime} 10^{\prime \prime} \mathrm{N}$, $30^{\circ} 02^{\prime 2} 5^{\prime \prime}$, 19. III.2016, leg. Anlaş \& Yağmur.

Etymology - The specific epithet honors Prof. Dr. Ali Gök, Isparta, a specialist on Chrysomelidae, who has carried out important entomological researches in Turkey.

Description - Habitus as in Figure 1. Body 4.5-4.7 mm long. Coloration: head reddish brown, pronotum and elytra reddish, with the posterior area slightly lighter; abdomen blackish brown with the narrow posterior margins of the tergites and the apex somewhat paler, legs and antennae reddish.

Head transverse, 1.22 times as wide as long (Figs 1-2); dorsal surface convex, with very dense, average size, granulose but rather shallow punctures; interstices reduced to narrow ridges; pubescence short and reddish yellow. Eyes relatively small, in dorsal view distinctly shorter than postocular region. Antennae moderately slender, $1.1 \mathrm{~mm}$ long, antennomere III approximately 2.2 times as long as wide; antennomeres V-X oblong (Fig. 1).

Pronotum transverse, approximately 1.20 times as wide as long (Figs 1-2); slightly wider than head; widest at anterior angles, narrowed posteriorly; anterior and posterior angles each with a long setae of little more than half the length of the lateral margin of the pronotum; posterior margin convex; dorsal surface with pronounced impressions; microsculpture barely noticeable; punctation similar to that of head, but denser, not granulose, surface somewhat more shiny than that of head; pubescence of similar length as that of head, but less fine and more conspicuous.

Elytra distinctly transverse and short (Figs 1-2), about 1.70 times as wide as long and approximately 0.70 times as long as pronotum; microsculpture absent; punctation dense and distinctly granulose, interstices on average approximately as wide as diameter 

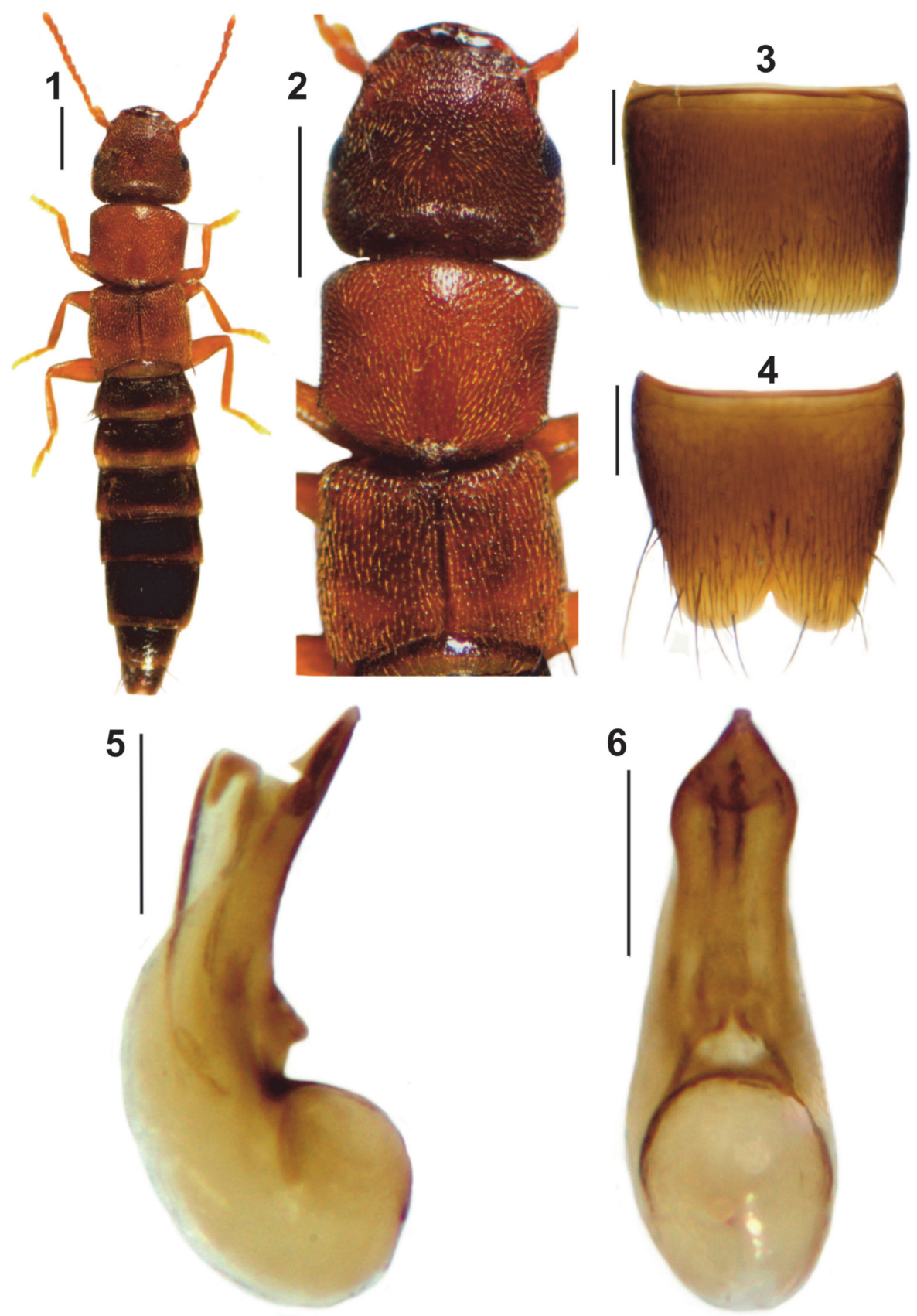

Figs 1-6. Details of Astenus (Eurysunius) goeki sp. n.: 1 = habitus, $2=$ forebody, $3=$ male sternite VII, $4=$ male sternite VIII, $5=$ aedeagus, lateral view, $6=$ aedeagus, ventral view. Scale bars: $0.5 \mathrm{~mm}$ for Figs (1-2) and $0.2 \mathrm{~mm}$ for Figs 3-6 
of punctures; pubescence reddish yellow, more distinct than that of head and pronotum; posterior margin of each elytron with 5-6 long black setae. Hind wings totally reduced.

Abdomen approximately as wide as combined width of elytra (Fig. 1), widest at segment V, segments III-VI transverse, tergites III-V slightly more than twice as wide as long; punctation very dense and very fine; interstices with distinct fine microsculpture; pubescence brown; posterior margin of tergite VII with palisade fringe.

$\delta$ - sternite VII in posterior median area slightly depressed and with some modified dark and short setae, posterior margin weakly concave (Fig. 3); sternite VIII deeply and acutely incised posteriorly, pubescence unmodified (Fig. 4); aedeagus approximately 0.65 $\mathrm{mm}$ long and as in Figures 5-6.

Comparative notes - The species is distinguished from all its consubgeners by the male sexual characters, especially by the ventral process of the aedeagus, which is of different shape, particularly in lateral view. In addition, the new species differs from all species in the western Anatolia by a different coloration (see key to the Turkish Eurysunius species below).

Distribution and bionomics - The new species was collected from the Alacadağ, in southwest of Antalya province, in grassland at altitudes of 1620 and $1810 \mathrm{~m}$. They were found in the nests of Tetramorium sp., which supports past observations suggesting that this subgenus is associated with these ants.

\section{KEY TO THE TURKISH SPECIES OF THE SUBGENUS EURYSUNIUS}

The keys to Turkish Eurysunius species in Assing (2002, 2007, 2010, 2011, 2013, 2015) and ANLAş (2014, 2015, 2016) are modified as follows:

1. Lateral margins of pronotum with one seta at antenor angle; elytra with yellow coloration confined to posterior third. Northern Anatolia: Ordu A. bicoloratus Assing, 2002

- Lateral margins of pronotum with more than one seta

2. Lateral margins of pronotum with two setae at anterior and posterior angles

- Lateral margins of pronotum with three setae; one at anterior angle, one at anterior third, and one at posterior angle

3. Pronotum approximately as wide as long

Pronotum transverse

4. Elytra uniformly yellowish or with yellow coloration confined to posterior half; legs and antennae yellowish red. Northern Anatolia: Bolu, Kastamonu

A. paphlagonicus Assing, 2002 
- Elytra narrowly yellowish; legs and antennae reddish or reddish brown

5. Posterior $1 / 6-1 / 5$ of the elytra yellowish; antennomeres IV-X approximately as long as broad to weakly transverse. Greece: Rhodes; Southwestern Anatolia: Muğla

A. rhodicus Assing, 2013

- $\quad$ Posterior $1 / 8$ of the elytra yellowish antennomeres; IV-X nearly 1.5 times as long as broad. Central-northwestern Anatolia: Bursa (Uludağ)

A. brachati Assing, 2011

6. Pronotum wider than head

- Pronotum narrower than head

7. Pronotum distinctly (approximately 1.20 times) wider than head. Centralwestern Anatolia: Afyonkarahisar, Konya

A. sultanicus Assing, 2010

- $\quad$ Pronotum slightly (approximately 1.05 times) wider than head. Western Anatolia: Denizli (Gölgeli Mountains)

A. occiduus Assing, 2007

8. Head and pronotum blackish or dark brown

- Head and pronotum reddish or reddish brown

9. Forebody completely blackish. Central-western Anatolia: Uşak and Kütahya

A. kumlutasi Anlaş, 2015

- Forebody not completely blackish

10. Forebody blackish, with posterior $1 / 3$ of elytra reddish. Western Anatolia: Aydın, Izmir

A. orgeli Anlaş, 2015

- Forebody blackish or dark brown, posterior half of elytra reddish-yellow. Central-western Anatolia: Afyonkarahisar (Ahir Mountains)

A. ilgazi Anlaş, 2016

11. Dorsal surface of pronotum without pronounced impressions; head, pronotum and elytra completely reddish brown. Central-western Anatolia: Afyonkarahisar (Sandıklı Mountains) A. sandiklicus Anlaş, 2014

- $\quad$ Dorsal surface of pronotum with pronounced impressions; head, pronotum and elytra not completely reddish brown

12. Head darker than pronotum and elytra; head reddish brown, pronotum and elytra reddish, with the posterior area slightly lighter. Southwestern Anatolia: Antalya A. goeki sp. n.

- Head not darker than pronotum and elytra 
13. Head and pronotum reddish brown, elytra yellowish brown, with area near scutellum, anterior margin, and anterior part of lateral margin infuscate, abdomen dark brown. Western Anatolia: Denizli (Çökelez Mountains)

A. gusarovi Anlaş, 2015

- Head, pronotum and abdomen reddish brown, more than anterior half of elytra dark brown, with posterior area reddish yellow. Western Anatolia: Denizli (Honaz Mountain)

A. honazicus Anlaş, 2015

14. Head broader than pronotum; legs and antennae yellowish brown; eyes distinctly shorter than postocular region. Central Anatolia: Kayseri

A. sexsetosus Assing, 2002

- Head approximately as broad as pronotum; legs and antennae reddish or blackish-brown, Eyes nearly as long as postocular region. Central Anatolia: Nevşehir

A. kociani Assing, 2015

Acknowledgments - I am most grateful to Dr. Ersen A. Yağmur and Semih Örgel for making their staphylinid collections available to me.

\section{REFERENCES}

Anlaş, S. (2014): A new species of Astenus (Eurysunius) Dejean, from Turkey (Coleoptera: Staphylinidae, Paederinae). Turkish Journal of Entomology 38(3): 239-243. https://doi. org/10.16970/ted.42581

Anlaş, S. (2015): Four new species of Astenus (Eurysunius) Dejean, 1833 from Western Anatolia, Turkey (Coleoptera: Staphylinidae, Paederinae). Zootaxa 3986(4): 472-482. https://doi.org/10.11646/zootaxa.3986.4.6

Anlaş, S. (2016): On the subgenus Eurysunius Reitter in Turkey III. A new species from western Anatolia and additional records (Coleoptera: Staphylinidae, Paederinae, Astenus). Turkish Journal of Entomology 40(1): 15-21. https://doi.org/10.16970/ted.11481

Assing, V. (2002): On the Turkish and Caucasian species of Eurysunius, subgenus of Astenus Dejean, with an appendix on A. breuili Jarrige (Coleoptera: Staphylinidae, Paederinae). Linzer biologische Beiträge 34(1): 265-274.

Assing, V. (2007): New species and additional records of Staphylinidae from Turkey V (Coleoptera). Stuttgarter Beiträge zur Naturkunde Serie A (Biologie) 700: 1-64.

Assing, V. (2010): On the Staphylinidae of Turkey. VII. Five new species and additional records (Coleoptera: Staphylinidae). Koleopterologische Rundschau 80: 71-102.

Assing, V. (2011): On the Staphylinidae of Turkey VIII. Eleven new species, two new synonymies, a new combination, and additional records (Coleoptera: Staphylinidae). Koleopterologische Rundschau 81: 179-227.

Assing, V. (2013): On the Staphylinidae of Rhodes, Greece (Insecta: Coleoptera). Linzer biologische Beiträge 45(2): 1587-1613. 
Assing, V. (2015): A new myrmecophilous species of Eurysunius from Turkey (Coleoptera: Staphylinidae: Paederinae). Linzer biologische Beiträge 47(2): 1113-1118.

Bolton, B. (1995): A new general catalogue of the ants of the world. Harvard University Press, Cambridge, $504 \mathrm{pp}$.

Coiffait, H. (1984): Coléoptères staphylinides de la région paléarctique occidentale V. Sous famille Paederinae, Tribu Paederini 2. Sous famille Euaesthetinae. Nouvelle Revue d'Entomologie, Supplément 8(5): 1-424.

Donisthorpe, H. Sт. J. K. (1927): The guests of British ants, their habits and life histories. George Routledge \& Sons, London, $244 \mathrm{pp}$.

Hölldobler, B. \& Wilson, E. O. (1990): The ants. Harvard University Press, Cambridge, Massachusetts, 732 pp. https://doi.org/10.1007/978-3-662-10306-7

Reitter, E. (1909): Fauna Germanica. Die Käfer des Deutschen Reiches. Nach der analytischen Methode bearbeitet. II. Band. K. G. Lutz, Stuttgart, 392 pp., 39 pls. [pls. 41-80.]

Sснӥlкe, M. \& Smetana, A. (2015): Staphylinidae, pp. 304-1134. - In: LöвL, I. \& Löвl, D. (eds): Catalogue of Palaearctic Coleoptera. Volume 2. Hydrophiloidea - Staphylinoidea. Revised and updated edition. Brill, Leiden, xxvi + $1702 \mathrm{pp}$.

Received January 25, 2016, accepted May 10, 2016, published March 3, 2017 


\section{Catalogue of Palaearctic Diptera}

edited by Á. SoÓs and L. PAPP

\section{Volume 13 \\ Anthomyidae-Tachinidae}

The Catalogue contains the basic taxonomic, nomenclatorial and distribution data of all species occurring in the Palaearctic Region with the fundamental morphological features for the majority of the fly groups.

Volume 13 lists the names of 460 genera, 38 subgenera and 2389 species assigned to three families. Furthermore, 672 synonymous generic and 2477 specific names, 1807 emendations, errors, nomina dubia and doubtful genera and species are listed. The period of the Catalogue extends from 1758 to 31 December, 1982.

Contents: Explication to distribution. Type-species designations in Volume 13. New names proposed in Volume 13. Families: Anthomyiidae (Á. DELY-DRASKOVITS). Rhinophoridae (B. HERTING). Tachinidae (B. HERTING and Á. DELY-DrASKOVITS). Bibliography. Index.

\section{December 15, 1993. 624 pages \\ ISBN 9630539101 (Series) \\ ISBN 9637093214 (Vol. 13)}

US $\$ 85.00$ plus US\$ 8.00 for package and postage (and an extra US\$ 5.00 if you want it air mail)

Hungarian Natural History Museum, Budapest

\section{Order should be sent}

to the Hungarian Natural History Museum, Library

Baross u. 13., Budapest, H-1088 Hungary

Fax: (36-1) 3171669 